Int. J. Electrochem. Sci., 14 (2019) 5690 - 5706

\title{
Corrosion Evaluation of the Welded Zone between Carbon Steel and Stainless Steel Embedded in Concrete and Exposed to a Marine-Like Environment
}

\author{
Rosalba Hernández-Leos, ${ }^{1}$ J. T. Pérez-Quiroz, ${ }^{2}$ M. Martínez, ${ }^{2} J$. Torres,${ }^{1}$ F. Castañeda, ${ }^{1} J$. Morales, ${ }^{1}$ \\ René Antaño ${ }^{1, *}$ \\ ${ }^{1}$ Centro de Investigación y Desarrollo Tecnológico en electroquímica SC, Parque Tecnológico \\ Querétaro-Sanfandila S/N, Querétaro, México, C. P. 76703. \\ ${ }^{2}$ Instituto Mexicano del Transporte, km 12+000, Carretera No. 431, "El Colorado, Galindo", Pedro \\ Escobedo, Querétaro, México, C.P. 76703 \\ *E-mail: rantano@ cideteq.mx
}

doi: $10.20964 / 2019.06 .30$

Received: 23 June 2018 / Accepted: 4 October 2018 / Published: 10 May 2019

In this study, an evaluation of the corrosion susceptibility of concrete reinforcement steel welded to stainless steel is reported, which is proposed as a potential solution to the repair and rehabilitate structures. An evaluation was conducted over 390 days by measuring the corrosion potential and current density levels by electrochemical impedance spectroscopy applied to a solution that simulated a marine environment. The welded carbon-stainless steel samples were found to be more resistant to corrosion than the carbon steel samples. These results were confirmed by visual inspection, scanning electron microscopy and energy dispersive spectroscopy of the welded zone. These findings support the concept of rehabilitating structures by replacing damaged carbon steel with stainless steel welded to the remaining structures.

Keywords: Welded zone, Stainless steel-concrete, Marine corrosion, Impedance

\section{$\underline{\text { FULL TEXT }}$}

(C) 2019 The Authors. Published by ESG (www.electrochemsci.org). This article is an open access article distributed under the terms and conditions of the Creative Commons Attribution license (http://creativecommons.org/licenses/by/4.0/). 